\title{
Estado, ciência e política na Primeira República: a desqualificação dos pobres
}

MARIA HeLENA SOUZA PATTO

A PROCLAMAÇÃO DA REPÚBLICA não trouxe transformações econômicas, sociais ou políticas radicais, nem marcou o ingresso do Brasil no concerto das nações civilizadas. Ela não foi, como freqüentemente se afirma, o desfecho das questões religiosa e militar do fim do Império, dos excessos cometidos pela Coroa ou da insatisfação dos fazendeiros com a abolição da escravatura; não foi também fruto de uma antiga e irreprimível aspiração republicana nacional, que se teria manifestado desde os movimentos revolucionários ocorridos depois da Independência; muito menos, expressão do desejo libertário de segmentos oprimidos das classes populares ou dos anseios liberais de uma nascente classe média urbana, que os militares representariam (1).

A formação de uma classe média urbana liberal, a partir da segunda metade do século passado, teria sido, segundo tal versão, uma das mudanças sociais decisivas na preparação do fim do Império. Em sua Pequena história da República, Cruz Costa deu alento a essa interpretação: “a partir de 1850", ele diz, dá-se "uma incipiente industrialização. Imigrantes e indivíduos que não pertenciam à classe rural dão começo a pequenos estabelecimentos industriais e comerciais e, dos lucros obtidos em seus negócios, ampliam sua ação, dando origem a uma classe que contrapõe sua mentalidade pequeno-burguesa, seu espírito de precavida iniciativa, à mentalidade feudalista própria da classe agrária” (2).

Incapaz de sozinha alterar a sociedade, a classe média nascente, à qual se somavam empregados e funcionários, ter-se-ia cristalizado em torno de uma nova força: "a força militar, o Exército”, porta-voz dos ideais republicanos. A suposta identificação entre classe média e Exército, idéia-chave desta versão, é inequívoca: “ Industriais e comerciantes - a classe média civil -, ligados ao Exército nacional - a classe média militar - podem ter entre si discrepâncias de idéias, antagonismos, mas estão ligados pelo mesmo imperativo de alteração dos quadros vigentes, e por isso geram e executam a República” (3). 
Estudos recentes voltados para a classe média urbana e seu papel na passagem do Império para a República revelam que ela não era portadora de vocação democrática, não estava insatisfeita com o estado de coisas reinante e não afrontava a classe dominante. Dependente da elite agrária no Império, não terá situação muito diferente nas primeiras décadas da República e será, como regra, elitista, conservadora, anti-industrialista, agrarista. Longe de opor-se às oligarquias agro-exportadoras, identifica-se com seus valores aristocráticos, cultiva os mesmos gostos e opiniões, depende economicamente dela e assume posições no máximo reformistas, o que lhe permite aliar-se politicamente aos oligarcas sempre que os interesses destes pedem novas palavras de ordem e a ampliação do apoio da sociedade civil. Mais visível na cena política à medida que a urbanização escapa da dependência exclusiva da economia agrário-exportadora, adere em boa parte ao programa liberal reformista do Partido Democrático e desempenha nos anos 20 e 30 papel importante na luta pelos direitos civis, como o direito à escola, na qual buscava uma via de validação social.

Por sua vez, nem os militares que se aglutinaram em torno de Deodoro da Fonseca, nem os jovens oficiais que apoiaram Floriano Peixoto foram representantes dos interesses de uma classe social. Inspirados no Positivismo, os tenentes declararam-se "soldados-cidadãos", rebelaram-se contra o governo federal e queriam salvar o país, pondo-o no rumo do progresso técnico e industrial. Fiéis à ideologia das Forças Armadas, queriam um Executivo forte, eram contrários à idéia de federação e "não acreditavam que o 'liberalismo autêntico' fosse o caminho para a recuperação do país. Faziam restrições às eleições diretas, ao sufrágio universal, insinuando a crença em uma via autoritária para a reforma do Estado e da sociedade" (4). Quando se referiam às massas, era para declará-las incapazes de contestação eficaz e assim justificar uma postura tutelar que encobria o objetivo de impedir a ação política direta do povo (5).

A República foi, acima de tudo, resultado de uma cisão da classe dominante que se configurou ao longo do Segundo Reinado. As tensões que movimentaram o país em direção à República tiveram origem, segundo Viotti da Costa, na quebra de unidade da classe dominante brasileira em função de mudanças econômicas que ocorreram a partir de 1850 e resultaram no exercício cindido do poder econômico e do poder político. O conflito básico que traz o fim do período monárquico não se dá entre um Brasil moderno, progressista, desejoso de democracia, representado pelas classes médias urbanas, e um Brasil conservador, regressista, afeito a concepções políticas totalitárias, representado pelas classes oligárquicas do Império; os grupos em confronto são dois setores da classe que garantira a sobrevivência 
do regime imperial: de um lado, as chamadas oligarquias tradicionais dos senhores de engenho do Nordeste e dos barões do café do Vale do Paraíba (monarquistas, escravistas, decadentes), apegadas a relações de trabalho e a formas de produção caducas, mas detentoras de poder político; de outro, as novas oligarquias dos fazendeiros do café do Oeste paulista que, embora ocupando lugar central na economia do país, não dispunham de poder político (6).

Foi em busca desse poder que, em 1873, organizaram o Partido Republicano Paulista, que teve entre os fundadores uma maioria de cafeicultores de Itu e Campinas. Já em 1894, os militares foram afastados do comando e a eleição do civil paulista Prudente de Morais pôs à frente do processo político cafeicultores paulistas e a elite econômica e política mineira, os quais instalaram um "situacionismo permanente", só rompido com a revolução de 30 , quando houve nova composição política no interior das elites. A ameaça de instabilidade política trazida pelos primeiros anos republicanos, em especial nos centros urbanos maiores, entre os quais se destacava a capital do país, levou os donos do dinheiro não só a tirar os militares do governo, mas a reduzir o nível de participação popular, neutralizar a capital e fortalecer o poder dos estados (7). E o veto à participação política do povo vinha não só da represssão policial às manifestações em praça pública, mas de outras restrições impostas à cidadania, entre as quais uma legislação eleitoral que reduzia ao mínimo os votantes: no Rio de Janeiro, subtraídos da população total os menores de 21 anos, as mulheres, os analfabetos, os praças, os religiosos e os estrangeiros, excluíam-se do direito ao voto $80 \%$ da população. Assim, “a República conseguiu quase literalmente eliminar o eleitor", motivo pelo qual "os representantes do povo não representavam ninguém, os representados não existiam, o ato de votar era uma operação de capangagem". A maioria dos votos era falsa: "votavam defuntos e ausentes, e as atas eram forjadas" (8).

As relações de produção em vigor abrangiam várias formas de exploração do trabalho. No campo, vínculos empregatícios contaminados pela prática do favor prendiam empregados a patrões por dívidas muitas vezes impossíveis de saldar e configuravam situações que beiravam à escravidão. Na cidade, o panorama não era diferente: uma massa de trabalhadores pobres acumulava-se no espaço urbano e vendia sua força de trabalho a preços que degradavam a vida, quando não a inviabilizavam, ou dedicava-se a outras ocupações, em nome da sobrevivência. Sem alternativas no mercado de trabalho, muitos ex-excravos e seus descendentes viviam em situação de desemprego crônico ou agregados a famílias ricas, onde exerciam extensas jornadas de trabalho doméstico não-remunerado. 
Os imigrantes, por sua vez, lutavam contra as dores do desenraizamento, do preconceito e das “duras condições de existência, resultantes das condições gerais de tratamento dos trabalhadores no país, onde quase equivaliam aos escravos" (9). A ausência de leis que garantissem os direitos básicos dos trabalhadores sancionava uma jornada de trabalho fabril esgotante, que podia chegar a 17 horas ininterruptas; a inexistência de férias e de repouso remunerado; salários aviltantes, ainda mais baixos no caso de mulheres e crianças, que em 1920 correspondiam a 43\% dos trabalhadores industriais na cidade de São Paulo (10). Tudo isso fez da Primeira República lugar privilegiado do que Antonio Candido chamou de "esquema decididamente espoliador que está na raiz da nossa sociedade” (11).

O Brasil da Primeira República não foi industrial: segundo o Censo de 1920, 69.7\% da população economicamente ativa dedicava-se à agricultura, $16.5 \%$ ao setor de serviços e $13.8 \%$ à indústria, quadro que não se alterou significativamente até 1930. Mesmo assim, o crescimento da indústria nesse período não pode ser subestimado: fábricas de médio e de grande porte de fiação e tecelagem, bebidas, roupas, sapatos e alimentos, instaladas no Rio e em São Paulo desde o começo do século, empregavam um número crescente de operários e submetiam homens, mulheres e crianças a condições desumanas de trabalho. Segundo Fausto, ao reestruturar as relações de trabalho por meio do colonato e do proletariado urbano, a burguesia cafeeira ampliou a base da pirâmide social e criou condições para o surgimento de questões sociais inéditas no campo e na cidade que teve de enfrentar: no período de 1917 a 1921, os pequenos jornais libertários registravam inúmeros episódios de resistência em fábricas paulistas que muitas vezes não tinham a visibilidade social dos movimentos grevistas, como operações-tartaruga e destruição de matéria-prima, de máquinas e de prédios, no caso de operários da construção (12). Além das greves e dos movimentos organizados das classes populares contra a inflação, a criminalidade crescia nas cidades maiores. E o fato a ser sublinhado é a freqüência com que se recorreu à violência física para fazer frente a todas essas manifestações.

\section{A presença do aparato repressivo}

A República nasceu sob o signo da ordem pública. Herdeiros de concepções político-filosóficas de cunho evolucionista que naturalizavam o social, intelectuais e militares que fundaram a República defendiam a tese do progresso ordeiro. O caráter nada revolucionário do movimento republicano brasileiro já era visível no Manifesto Republicano de 1870: seus signatários apresentavam-se "como homens livres e essencialmente 
subordinados aos interesses da pátria”, que não pretendiam convulsionar a sociedade, muito menos romper com a estrutura vigente. No Decreto $\mathrm{n}^{\circ} 1$, de 15/11/1889, os membros do recém-criado Governo Provisório afirmam repetidas vezes a "defesa da ordem pública" como objetivo maior.

O horror aos movimentos sociais, à sublevação popular, à oklocracia, como se dizia no Império, é marca registrada dos plutocratas de todos os tempos. Em 1831, dominados os motins de soldados que falavam em República, em destituição do governo e em Constituinte soberana, o Regente Feijó dizia: “o brasileiro não foi feito para a desordem, que o seu natural é o da tranquiilidade e que ele não aspira outra coisa além da Constituição jurada, do gozo de seus direitos e de suas liberdades." Portadores da vocação não-democrática inscrita num "liberalismo regressista”, os intelectuais do Império tinham repulsa declarada à democracia e à revolução, e desde o Primeiro Império já falavam em "parar o carro revolucionário" (13).

O movimento abolicionista não foi exceção à regra; pautado pelo lema liberal da "liberdade, igualdade, fraternidade", seu caráter humanitário não passou de aparência: "promovida principalmente por brancos, ou por negros cooptados pela elite branca, a abolição libertou os brancos do fardo da escravidão e abandonou os negros à sua própria sorte" (14) No curso da República Velha, a “máquina de compressão das liberdades públicas” (15) foi incansável. Inicialmente no bojo da luta pelo poder entre presidentes militares e parte da elite que precisava da autonomia dos estados e, pouco depois, como resposta oficial aos movimentos de trabalhadores, a decretação do estado de sítio foi prática corrente de sucessivos presidentes que suprimiram as leis ordinárias e submeteram o país ao regime de guerra sempre que encontraram oposição aos interesses que representavam.

A busca de instituições de gestão científica do protesto e da miséria nesse período esbarra de pronto na onipresença da polícia. A "sutil violência repressiva", a "predominância da penalidade incorporal", a "sobriedade punitiva" encontradas por Foucault em países europeus na virada do século XVIII (16) não estão presentes na Primeira República. Sob a alegação de que estavam em jogo interesses do conjunto da Nação, o Estado brasileiro primeiro-republicano não agia com sutileza disciplinadora para garantir a ordem pública. Ao contrário, os donos do poder não hesitaram em valer-se, até a náusea, da violência física para imobilizar os indesejáveis. Este fato põe em dificuldade a tese de inspiração foucaultiana segundo a qual, no marco das greves operárias do primeiro período republicano, a ineficácia das medidas punitivas e policialescas de controle da força de trabalho teria 
levado à introdução de tecnologias de adestramento e controle nas fábricas e de gestão científica da miséria lideradas por médicos, quer pela higienização dos corpos e das casas populares, quer pela imposição ao povo de normas familiares burguesas, quer pela apropriação da infância pobre pelo saber médico, quer pela expansão de instituições disciplinares como hospícios, reformatórios e escolas.

Todo esse período foi marcado por um sem-número de exemplos de brutalidade repressiva, orientação professada pelos governantes, apoiada por industriais e fazendeiros e muito bem resumida pelo presidente Washington Luís (que fora Secretário da Justiça e da Segurança Pública do Estado de São Paulo) quando definiu a "questão social" - que era como então se chamavam os conflitos sociais - como "caso de polícia". Foi assim na greve de operários numa fábrica de sapatos no Rio de Janeiro, em 1902; no movimento grevista na Cia. Doca de Santos, em 1904; na greve de ferroviários paulistas, em 1906; na Revolta da Chibata, em 1910, quando marinheiros negros e mulatos rebelaram-se contra o uso do chicote como instrumento de punição na Marinha; em Juazeiro e no Contestado; na greve de colonos das fazendas de café da região de Ribeirão Preto, em 1913; na primeira greve geral que parou cerca de 50 mil trabalhadores da cidade de São Paulo, em 1917; na greve da Cia. Mogiana, em 1920, e assim por diante. A partir de então intensificaram-se as práticas repressivas, pois “a piedosa simpatia pelos 'deserdados da fortuna', pelos 'humildes', por aqueles que os 'maus fados' haviam irremediavelmente fixado no fundo dos estratos da sociedade, começa a converter-se em inquietude quando a desarticulada massa ameaça ultrapassar os limites e transformar-se em classe social" (18), repressão que atingiu em cheio líderes operários, principalmente os estrangeiros, conforme ficou registrado no Manifesto de Deportados. Além de deter o protesto proletário, cabia à polícia recalcar toda sorte de comportamento desordeiro - que mudanças no Código Penal tratavam de criminalizar -, tarefa que cumpriu com ímpeto, pois nas quatro primeiras décadas republicanas o número de detenções em São Paulo foi quase três vezes maior do que na Londres do mesmo período. Dados colhidos nos relatórios de secretários da Justiça e de chefes de Polícia da capital paulista no período de 1890-1924 mostram que a maior parte das prisões entre 1892 e 1916 se deu por prática de contravenção (83.8\%), ou seja, de crimes sem vítimas, como "embriaguez", "desordem" e "vadiagem". Nesta categoria estavam também os "suspeitos" e os detidos para "averiguações", fato sugestivo no terreno social de então. E o número de detenções elevou-se à medida que o aparato policial cresceu pari passu com a preocupação com a ordem pública (18). Como explicar esse aumento de atos considerados criminosos nas cidades brasileiras do começo do século? 
É no âmbito da luta da classe trabalhadora e de sua auto-organização que certas modalidades de crime presentes na Inglaterra que se industrializava são entendidas na historiografia social inglesa contemporânea. Naquele tempo e naquele lugar, a luta das classes proprietárias pela transformação do salário em forma exclusiva de remuneração incluiu não só um surto de legislação criminal e de novas formas de repressão que criminalizavam as formas de remuneração não-monetária sancionadas pelo costume (como a apropriação das sobras da matéria-prima), mas também transformações nas técnicas de produção e nos locais de trabalho, que visavam a eliminar as sobras e impedir o roubo. Em contrapartida, várias formas de resistência à extorsão dos meios de trabalho, ao constrangimento do trabalho assalariado e aos baixos salários - a cunhagem de moeda, o assalto a estradas, $\mathrm{o}$ jogo, $\mathrm{o}$ roubo de carga etc. - proliferaram entre os trabalhadores que se concentravam na Londres setecentista em busca de dinheiro e marcaram o surgimento do "proletário picaresco" e da primeira força policial assalariada, armada e centralizada (20).

Assim, a organização policial foi, naquele contexto, parte da estratégia de formação de um mercado capitalista de trabalho assalariado. Mas convém indagar se o processo de constituição da classe trabalhadora brasileira equivale ao da classe operária inglesa: num país essencialmente agrícola, no qual os artesãos não tiveram a força numérica e organizatória encontrada na Europa - a indústria capitalista de transformação em suas formas nãofabris não assumiu nem de longe as proporções assumidas no berço do capitalismo industrial e as relações de trabalho acabavam de sair de séculos de escravismo e ainda estavam permeadas pelo sistema de clientela certamente não houve necessidade de quebrar a espinha da classe trabalhadora ou forçá-la ao trabalho assalariado na proporção e nos moldes da Inglaterra da revolução industrial. Por mais obstinado que fosse o movimento operário, ele tinha menos força num país no qual o sistema de dominação prescindia dos trabalhadores, pois "a sólida oligarquia se assenta em um pacto de alianças regionais de cúpula, cimentado pelo controle de uma clientela principalmente de base rural" (20). Sendo assim, cabe perguntar se a presença da polícia brasileira entre 1889 e 1930 comporta a mesma interpretação que historiadores marxistas deram à ação policial no interior da revolução industrial inglesa.

O cotidiano e a sobrevivência das classes populares urbanas tinham aqui características próprias (21). Explorados nos novos sistemas dominados pelo salário ou, em sua maioria, fora deles, os nossos pobres procuravam ganhar a vida por meio de expedientes que os punham em conflito com a lei, mas que não assumiam a forma de crime organizado nos moldes das 
quadrilhas européias de antigos membros de corporações profissionais e comerciantes extorquidos de seus meios de trabalho. Os crimes com vítimas que pipocavam dia e noite na cidade de São Paulo eram, na maior parte, pequenos furtos oportunistas ou gatunagem (22); vivendo em "lastimável pindayba” (como dizia uma notícia do Correio Popular, em 1808), os nossos infratores batiam carteiras e roubavam lingüiça, queijo, latas de goiabada, roupas, sapatos e galinhas, fosse para consumo próprio, fosse para vendêlos a preço irrisório a comerciantes que lucravam com a venda de produtos roubados (23). Tínhamos também os nossos jogadores, vigaristas e falsificadores profissionais, mas longe em organização e número do quadro descrito na historiografia inglesa. Nos dados oficiais predominavam "os pequenos crimes espontâneos, individuais, de miseráveis que não estavam organizados em quadrilha, sem projeto e sem dinheiro, roubos de subsistência, infratores não por escolha, mas pelas circunstâncias, por passar por profundas privações" (24). Noutras palavras, abundava um tipo de crime "que nasce e tem fortes raízes na miséria" (25), e que não pode, portanto, ser considerado resistência política à expropriação dos meios de produção, à dominação e à exploração como o foram certos crimes proletários da Inglaterra industrial dos séculos XVIII e XIX.

Nos registros policiais da cidade de São Paulo três fatos sobressaem: os estrangeiros eram maioria na categoria "desordem", ao passo que os brasileiros predominavam nas ocorrências de "vadiagem"; os rótulos oficiais usados para classificar as infrações eram pejorativos; o número de detenções superava em muito o número de processos (26). Dizer que a massa de "vadios" era formada de negros e mulatos desocupados os quais, desde a Abolição, viviam à margem da sociedade, e que os estrangeiros predominavam entre os "desordeiros" porque sua condição de imigrantes os tornava mais propensos ao desajuste social-emocional é uma interpretação que elide aspectos indispensáveis à compreensão da situação da classe trabalhadora na Primeira República. Na categoria de "vadios” estavam, sim, negros deixados à própria sorte desde a Abolição e objeto de preconceito racial, mas também toda uma gama de "pobres livres" cujo trabalho era socialmente desnecessário. A luta diária pela vida levava-os a improvisar vários tipos de afazeres, desde ocupações autônomas, bicos e subemprego temporário, que movimentavam a economia informal, até outras formas de sobrevivência, como o roubo, o jogo, a prostituição e a mendicância.

Do mesmo modo, não era por acaso que os imigrantes engrossavam as estatísticas de detenção por "desordem”, pois não só embriagados e briguentos que perturbavam o espaço público eram enquadrados como desordeiros: "se consultarmos outras fontes que não os registros das auto- 
ridades policiais, como por exemplo os jornais, principalmente a imprensa operária, verificaremos que também são presos como desordeiros: anarquistas, socialistas, sindicalistas, grevistas, propagandistas anti-religiosos, anti-voto, feministas etc.” (27). O caso dos capoeiras é exemplar: no Código Penal de 1890 havia um capítulo voltado para os Vadios e Capoeiras, e o Artigo 402 criminalizava a capoeiragem (28). Como os grupos de capoeiras sempre incluíram escravos e libertos, configurava-se um caso de perseguição racial legalizada. Da mesma forma, durante muitas décadas os famigerados "malandros cariocas" - os nossos pícaros? - compareceram envoltos em preconceito nos relatórios policiais e nos boletins dos Departamentos Estaduais do Trabalho.

A atenção aos termos usados pelo aparato repressivo para classificar pessoas e comportamentos sociais indesejados é fundamental à tarefa de desvendar mecanismos de controle social em ação na sociedade brasileira. “A estigmatização de camadas destituídas com o rótulo de 'vadios' é um dado que percorre a História brasileira desde o período colonial" (29). Nos relatórios oficiais, desempregados e subempregados compareciam como "vadios", como "incansáveis parasitas", como "sanguessugas" que se alastravam pelas cidades atacando a propriedade com "cínica temeridade" (30). A preocupação obsessiva de cientistas e autoridades policiais nos países industriais europeus com a "vagabundagem" repetia-se aqui, embora não pelos mesmos motivos. Bastava ser pobre, não-branco, desempregado ou insubmisso para estar sob suspeita e cair nas malhas da polícia.

Sem nenhum poder a opor ao poder policial, os pobres eram detidos a todo momento e adensavam as estatísticas criminais. Segundo Fausto, entre 1890 e 1924 o número de detenções superou em muito o número de processos. Em 1905, por exemplo, os detidos foram mais de $11 \mathrm{mil}$, enquanto que os processados ficaram em torno de 800 . Uma das causas dessa defasagem pode ter sido a pouca importância dos delitos, que não justificava a abertura de processos; a corrupção do aparelho policial também pode responder por certo número de casos, mas não se pode desconsiderar que a arbitrariedade era a regra quando se tratava de trancafiar os pobres. Assim, boa parte das detenções podia não ser passível de processo pelo simples fato de que não havia delito, mas só ação da mais pura prepotência. Um fato relatado pela imprensa dá força a esse argumento: em 1904, a polícia do Rio e de São Paulo, “aproveitando-se do Estado de sítio, efetuava a prisão indiscriminada de pessoas tidas como vagabundos e cáftens, algumas das quais estavam sendo enviadas para o Acre" (31). Propostas de enfrentamento pacífico da "questão social” reveladoras de "óticas heterogêneas no interior da própria classe dominante" (32) também estiveveram presentes 
na Primeira República, formuladas por homens públicos de prestígio, como Rui Barbosa, e por instituições político-partidárias de “oposição". Avessas a mudanças sociais radicais, preconizavam a adoção de estratégias que diminuíssem a intervenção das forças policiais, de modo que alguma coisa mudasse, na aparência, para que tudo, em essência, continuasse como estava, ideologia que se fez presente a partir da greve que parou São Paulo em 1917 e, pouco depois, encontrou forma na idéia de fazer a revolução antes que o povo a fizesse. Mas não passaram de palavras, e o grosso da função de disciplinamento do povo ficou por conta das instituições jurídico-policiais, constantemente reorganizadas e ampliadas nos mais de 40 anos do primeiro período republicano.

Entre 1897 e 1930 ocorreram em São Paulo sucessivas rearticulações das instituições repressivas. Em 1897 o antigo Corpo Policial Permanente transformou-se em Brigada Policial, diretamente sob as ordens do presidente do Estado; criou-se a Guarda Cívica da Capital, subordinada ao chefe de Polícia, para policiar o centro da cidade, os divertimentos, os festejos e as solenidades públicas e a Guarda Cívica do Interior, sob as ordens do secretário de Justiça, substituiu a antiga Polícia Local do Império. Ao longo desse período, a Brigada Policial tornou-se Força Pública, o que demandou investimento de significativa parte da dotação orçamentária do Estado na melhoria das condições materiais da instituição, no treinamento e aperfeiçoamento de seu contingente, na instalação de um plano de carreira, no aumento de salários e, acima de tudo, na militarização não só da instituição, mas de seus agentes, mediante um trabalho de doutrinação que os distanciava de sua origem de classe pela identificação com a ideologia do Estado (33). Transformada em "pequeno exército" dos donos do poder regional, a Força Pública lutou contra as ingerências do governo federal, reprimiu movimentos trabalhistas e participou de operações de "faxina urbana". Desde os primeiros anos do novo século, os gastos com a polícia e as prisões eram duas vezes maiores do que com a saúde pública.

Se considerarmos que muitas das medidas saneadoras não eram manobras disciplinadoras comandadas pelos médicos, mas imposição das más condições de saneamento básico advindas do crescimento demográfico nos centros urbanos, é duvidoso que, nesse período da vida brasileira em que a atenção das autoridades estava voltada para o fortalecimento do aparato repressivo, os médicos tenham se apropriado do espaço urbano, como afirmam historiadores brasileiros que operam uma transposição mecânica das conclusões de Foucault a respeito de países do Oeste europeu nos séculos XVIII e XIX. No interior de um confronto de classes absolutamente desigual, o que predominou foram os punhos cerrados da polícia, para quem, no 
Brasil, as leis nunca tiveram muita importância e o abuso de poder sempre foi a regra. Basta lembrar que, enquanto operários estrangeiros eram espancados e deportados, "com relação aos trabalhadores nacionais utilizouse freqüentemente o expediente da prisão não-comuni-cada às autoridades judiciárias e a soltura dos presos, tempos depois, sem recurso, fora de seu Estado" (34). Ao contrário do que ocorreu em Minas na segunda metade do século XVIII - quando a sociedade civil foi purgada dos perturbadores pelo trabalho forçado de "vadios e facinorosos" na construção de prédios públicos (35) -, as operações policiais na Primeira República não pretendiam outra coisa senão excluir e, sempre que possível, exterminar os que ameaçavam a paz da burguesia ou o projeto eugênico de progresso do país.

O uso permanente, sem-cerimônia, ilegal e impune do aparato policial para estancar o protesto dos espoliados, tirar de circulação a força-detrabalho desnecessária e restabelecer a ordem social nos moldes requeridos pelos interesses da classe dominante foi traço profundo da vida social brasileira nesse período, aliado à incipiência das instituições de disciplinamento mais hábil. E a brutalidade sem tamanho da polícia contribuía para aumentar ainda mais "a distância entre o país real e o país legal” (36), o que indica que fazer valer as leis, e não substituí-las pela norma, era a grande dívida da classe dirigente brasileira para com o ideário liberal que professava. Numa sociedade na qual o medo da polícia era poderoso instrumento disciplinador, a barbárie um fato e a cidadania não estava nem mesmo no horizonte mais remoto faz sentido perguntar se o disciplinamento dos pobres esteve por conta de médicos e educadores.

\section{Realidade e mito do movimento higienista}

O aspecto geral da cidade do Rio de Janeiro na virada do século ainda era, segundo cronista da época, o mesmo do tempo dos vice-reis, exceção feita à paisagem humana. Acrescida de escravos libertos vindos de vários pontos do país, migrantes nacionais e estrangeiros, funcionários públicos, empregados no comércio e no setor de serviços, todos eles pressionados por desemprego, inflação e baixos salários, a vida na cidade resultou no chamado "caos urbano" e no recrudescimento de questões recebidas do Império: a crise habitacional "persistiu e se agravou depois da proclamação da República”, "as epidemias reinavam com intensidade jamais vista" e problemas de saúde pública desafiavam as autoridades. O conjunto de medidas sanitárias para a cidade do Rio, aprovado em congresso médico realizado em 1889, incluía mudanças na planta da cidade e ações drásticas de vigilância sanitária reunidas numa operação que ficou conhecida como 
“o bota-abaixo". Levada a efeito a partir de 1903 pelo então prefeito carioca Francisco Pereira Passos, ela modernizou o porto, promoveu a abertura de avenidas e praças, erradicou moradias coletivas, alargou calçadas e ruas, melhorou a circulação do tráfego, expandiu a área urbana (37).

Tanto em São Paulo como no Rio os relatórios técnicos dos sanitaristas terminavam encarecendo a necessidade de intervenção do poder público na prevenção de problemas de saúde pública, entre outras medidas, por meio da construção de casas populares baratas e higiênicas. Na São Paulo de 1886 o Código de Postura do Município já alertava para o perigo das epidemias, e continha um capítulo sobre cortiços, casas de operários e habitações dos pobres (38). Desde o fim do século XIX a questão da moradia popular estava no centro das atenções; depois da epidemia de febre amarela de 1893, a Administração Sanitária do Estado de São Paulo criou um Código Sanitário que determinava que fossem "proibidas as construções de cortiços e eliminados os já existentes”, além de normas rigorosas de construção e higiene de moradias, que inspetores sanitários tentavam fazer cumprir. Em 1917, o presidente da Liga Brasileira contra a Tuberculose denunciava, no I Congresso Médico Paulista, “a crise de domiciliamento do operariado” e seus efeitos maléficos sobre a saúde coletiva. A cidade foi reurbanizada em moldes semelhantes ao que se fazia no Rio, embora em menor escala: rasgaram-se avenidas e alamedas, construíram-se fontes públicas, expandiram-se as redes de água e esgotos, de iluminação pública e de transportes coletivos e criaram-se novos bairros.

Tendo em vista as especificidades econômicas, sociais e culturais brasileiras, é preciso perguntar, como o fizemos em outro lugar com relação ao Império, se o movimento higienista repetiu-se aqui nas mesmas proporções e com os mesmos significados e resultados que teve num certo momento da Europa das revoluções econômica e política burguesas. O discurso e as medidas voltados para a "desordem urbana" certamente tiveram no Brasil motivações que não o ajustamento da força de trabalho às novas exigências da produção industrial; eles foram resposta autoritária, moralista e preconceituosa a questões que se puseram à burguesia durante o primeiro período republicano: a obsessão ordeira desencadeada pelo medo antigo e crescente que as classes dominantes tinham da revolta popular, potencializado pelos protestos de rua e pelo aumento das estatísticas criminais; o propósito sincero de alguns de enfrentar a gravidade real das condições sanitárias das cidades atingidas periodicamente pela peste; os interesses do capital comercial e financeiro internacional. Mas, no caso brasileiro, a campanha higienista esteve sobretudo a serviço de dois projetos da classe dominante: superar a humilhação frente ao "atraso" do país em relação aos 
"países civilizados", pela realização do sonho provinciano de assemelhar-se à Europa, e salvar a nacionalidade pela regeneração do povo.

$\mathrm{O}$ afă de andar no passo da cultura européia ainda estava presente na maior parte dos intelectuais da Primeira República e dava continuidade ao quadro de reações miméticas de amplas proporções que se viu no Império. Ambições aristocráticas continuavam a tomar conta da elite agrária brasileira, e a Europa, especialmente a França, ainda era espelho da burguesia nacional. Pouco antes da mudança do regime, a Marselhesa era o canto de guerra republicano e o 14 se julho considerado feriado até 1930. As justificativas das propostas modernizantes começavam invariavelmente com a informação do que existia na Europa. Francisco Pereira Passos, como tantos outros jovens da elite local, morou na França, onde fez cursos e acompanhou a reforma da capital francesa. O discurso sobre as cidades que tomou corpo no fim do século imperial tinha na base o desejo de embelezamento das cidades brasileiras, a oposição à sua falta de estética, a vontade de fazê-las elegantes, artísticas e modernas como a Paris remodelada (39).

Tal como acontecera no Império, higiene e beleza não raro compareciam geminadas no discurso das autoridades: falava-se em "regeneração estética e sanitária" do espaço urbano. Tudo o que fazia "feia" a paisagem urbana era objeto do olhar aflito da burguesia preocupada em não fazer má figura diante do mundo, motivo pelo qual aplaudia iniciativas que varressem as mazelas de um país bárbaro para debaixo do tapete, fossem elas cortiços ou vendedores ambulantes, quiosques ou mendigos. Em 1903, decretos punham sob o mesmo alvo ambulantes, pedintes e cachorros da cidade. Para que a cidade virasse vitrine de civilização era preciso esconder um povo que "não se enquadrava nos padrões europeus nem pelo comportamento político, nem pela cultura, nem pela maneira de morar, nem pela cara" (40). E o discurso estético, ao falar em eliminar edificações "carentes de inspiração artística”, camuflava interesses comerciais que movimentavam em surdina as obras de saneamento.

Havia também o medo, um medo ancestral de povo que tomava de assalto a classe dominante desde os tempos da escravidão, quando reações de rebeldia eram reprimidas com violência sem freio, tanto nas fazendas como nas aldeias e quilombos, cuja destruição mobilizou verdadeiras operações de guerra (41). Na Assembléia Constituinte de 1823 “a desconfiança em relação às camadas populares era tão generalizada (...) quanto o horror a uma sublevação de escravos" (42). O "medo branco" da "onda negra” esteve presente durante todo o século XIX (43), e foi tanto maior quanto mais na transição do trabalho escravo para o trabalho livre aumentou 
a concentração no espaço urbano de segmentos de classe privados de meios de vida. Tal fenômeno, somado ao desemprego causado pela política econômica, fez crescer a criminalidade e intensificou a angústia persecutória dos ricos frente à "escória", à "canalha", à "ralé", à "gentalha", o que só piorou com a Revolta da Vacina, em 1904, quando os movimentos populares começaram a fugir ao controle das elites e a arrebatar um número crescente de moradores das cidades. Nesse clima, ganhou prestígio a idéia de "euritmia social”, ou seja, de harmonia, de organização social "escoimada de vícios e de defeitos nefastos e perigosos que são para o meio coletivo equivalentes das taras individuais no organismo humano" (44). Rui Barbosa portava o medo do "espectro do caos" quando advertia, na revista da Faculdade de Direito de São Paulo, em 1909: “esse país viverá se crer na Justiça, no Direito e os santificar. Se não, rapidamente passará da desordem à anarquia, da anarquia ao caos, do caos à barbárie da delinqüência... uma raça perdida. Não há outra alternativa. Ou justiça, paz, prosperidade. Ou ditadura” (45).

Mas nem tudo era conspiração contra os pobres a serviço da ordem social, nem tudo era "tecnologia disciplinar", nem sempre os desígnios dos médicos correspondiam aos interesses do capital: objetivos saneadores legítimos e preocupação de alguns médicos com a saúde pública também estiveram presentes entre interesses escusos. Embora houvesse médicos que manobravam a tramitação de contratos e assinavam decretos que beneficiavam empreiteiras, havia também os que denunciavam irregularidades de companhias construtoras de obras públicas e casas populares. Informar sobre os benefícios do aleitamento materno não é necessariamente sutileza ideológica para subjugar as mulheres à maternidade; valorizar a instalação de redes de esgotos, a canalização da água em cidades populosas não é condenável desodorização dos pobres.

Quando a comissão que inspecionou habitações coletivas operárias escreveu em 1893 que na epidemia recente de febre amarela "a população operária pagou o maior tributo", pois que "suas condições de vida impelemna a acumular-se onde encontra mais facilidade de viver, e esta facilidade só se obtém em sacrifício da saúde", ela não as estava considerando insalubres por comparação com os padrões burgueses de higiene ou mistificando fatos em benefício dos interesses oligárquicos. Ao proporem casas higiênicas e confortáveis para o povo, nem sempre os higienistas queriam interferir em sentimentos e vontades individuais, tendo em vista discipliná-los. Da mesma forma, não é tão simples condenar a vacinação obrigatória em meio às epidemias do início do século, como também não se pode, sem mais nada, tomar por colaboradores do sistema os médicos que se preocupavam com os corpos amontoados nas penitenciárias. 
Se no âmbito das ações higiênicas do Estado nem tudo era estratégia para eliminar práticas populares ameaçadoras, nem toda reação popular era manifestação de contrapoder ou resistência política. $\mathrm{O}$ fato de a classe operária continuar a se aglomerar em moradias insalubres não pode ser tomado como prova de resistência surda à forma burguesa de habitar e à disciplina desodorizante. A presença continuada de péssimas condições materiais de existência entre os trabalhadores, apesar das políticas sanitárias, podia ter outras causas, como as ambigüidades e o descaso do Estado quando se tratava de levar o conforto do progresso ou de garantir a cidadania aos segmentos sociais espoliados, atitudes que resultaram em fracasso de alguns projetos de saneamento, para o desespero de alguns sanitaristas. De resto, tal como acontecera em Paris, onde "o bonapartismo com seu barão de Haussmann explorou no mais alto grau esta tendência ao aproveitamento máximo da especulação e do enriquecimento privado" (46), especulação, corrupção e enriquecimento privado orientavam a execução de obras públicas e atropelavam as prescrições de higienistas.

A especulação imobiliária e o fortalecimento de grandes grupos empresariais foram móveis pouco visíveis, mas poderosos, da reforma urbana que tomou conta do Rio na gestão Pereira Passos. Numa reedição dos efeitos da reforma de Paris, os pobres do Rio e de São Paulo foram afastados para áreas sem interesse imobiliário - pântanos, morros, barrancos, margens de rios e áreas localizadas nas bordas da cidade, no subúrbio, na sub-urbe. Estavam também em ação os interesses de produtores e comerciantes de produtos tropicais, pois as epidemias prejudicavam o comércio e desestimulavam a imigração. Um fato registrado por Benchimol dá apoio à tese segundo a qual as conveniências do capital falaram mais alto do que o propósito de melhorar a saúde pública ou disciplinar os pobres pela imposição de normas que lhes eram estranhas: sob protesto de alguns higienistas, um decreto proibia, no auge do bota-abaixo, obras que visassem à melhoria das condições dos cortiços situados no cobiçado centro da cidade. A origem da persistência da má qualidade de vida do povo estava nas relações de produção em vigor. A exploração brutal não deixava saída aos trabalhadores senão repor as condições miseráveis de existência e reinstalar a "desordem urbana" onde os poderosos insistiam em tirá-la de cena. Expulsos do centro do Rio, voltaram ao centro, não como forma de afrontar o poder constituído, mas como expressão da mais absoluta falta de alternativa.

Engels registrou esse processo em $A$ questão da habitação: "a burguesia só tem um método para resolver a questão da habitação à sua maneira - o que significa resolvê-la de tal modo que a solução sempre repõe a questão.” 
Ele chama de "método Haussmann" a estratégia que consiste em "abrir longas artérias largas e retas através dos quarteirões operários de ruas estreitas" de modo a dificultar as barricadas”, “ (...) a prática generalizada de abrir brechas nos bairros operários, sobretudo nos situados no centro de nossas grandes cidades, quer isso corresponda a uma medida de saúde pública, de embelezamento, de procura de locais comerciais no centro ou a exigências de circulação - instalar ferrovias, ruas etc." "Qualquer que seja o motivo", ele diz, "o resultado é sempre o mesmo: as ruelas e os becos mais escandalosos desaparecem e a burguesia vangloria-se deste imenso sucesso - mas ruelas e becos reaparecem imediata e freqüentemente nas vizinhanças" (47). Onde a espoliação é escandalosa e a miséria grassa não há possibilidade de realização pelos segmentos sociais mais explorados de padrões higiênicos prescritos por especialistas, sejam os mecanismos de imposição brutais ou sutis, mesmo que a limpeza seja um valor da própria cultura popular e faça parte da luta diária dos pobres por conforto e dignidade. Resistência eram as greves, as sabotagens, os atos contra a propriedade e a depredação de bens públicos não usufruídos pelos trabalhadores. Resistência eram as "repúblicas populares", instituições da cultura popular muitas vezes subterrâneas onde se forjavam novas manifestações coletivas mais fiéis às raízes brasileiras (48).

Assim como não se pode superestimar a resistência popular, tomando todos os seus comportamentos como sinais inequívocos de luta política contra a dominação, não se pode grifar o pólo da eficiência das estratégias disciplinares. A submissão aos padrões da cultura dominante não é absoluta. O povo apropria-se ativamente do discurso técnico que quer mudar os seus usos e costumes, normas e valores, atitudes e comportamentos ligados à tradição e à sobrevivência, como as práticas de criação de filhos, os padrões de relações familiares, os hábitos alimentares, os estilos de linguagem. Impostos, os modelos desejados pelos especialistas muitas vezes acabam comparecendo no imaginário e no cotidiano do povo de formas insuspeitadas pelos que querem submetê-lo (49). Os mesmos padrões de comportamento são passíveis de conteúdos de classe específicos: a família popular não resulta simplesmente da imposição da ordem burguesa, mas é lugar de subsistência, é "anteparo contra a penúria e a miséria" (50); mesmo que influenciados pelo ideal dominante, os operários possuem "suas próprias idéias sobre a divisão de papéis" (51); se perguntarmos “onde os dominantes vão buscar as prostitutas", o machismo operário e camponês, parte integrante da cultura popular brasileira, adquire outro sentido, torna-se "recurso ambíguo para proteger as mulheres, oprimindo-as" (52). E os estudos sobre a questão das práticas disciplinares não podem desconsiderar um traço da cultura brasileira que Antonio Candido chamou de "pólo da desordem": 
num país marcado pelo pluralismo racial e religioso, no qual o povo não foi formado no interior da ética protestante, não era "leitor quotidiano da Bíblia”, a obediência era mais problemática do que nos Estados Unidos e em países capitalistas europeus dos séculos XVIII e XIX. Enquanto naqueles países "houve desde cedo uma presença constritora da lei, religiosa e civil, que plasmou os grupos e os indivíduos, delimitando comportamentos graças à força punitiva do castigo exterior e do sentimento interior de pecado", aqui as formas espontâneas de sociabilidade "abrandaram os choques entre a norma e a conduta" (53). Especificidades culturais que não estavam no programa dos higienistas europeus interferiam, portanto, nos propósitos das classes dominantes locais, até mesmo nas assépticas vilas operárias.

Mais do que evidência de ímpeto disciplinador dos médicos, a violência com que o poder público brasileiro executava as leis e projetos de saneamento repetia a forma tradicional de relação entre dominantes e dominados. As ações repressivas em nome das medidas higiênicas aprovadas nos congressos médicos eram realizadas quase sempre sob a coordenação do secretário de polícia, a quem cabia vigiar usos e costumes, aplicar multas, promover despejos e dar voz de prisão aos infratores. A repressão grosseira, mais do que as sutilezas disciplinadoras, foi, portanto, o instrumento por excelência do movimento higienista brasileiro. A polícia era a presença mais concreta do Estado junto ao povo, tanto que, segundo jornais da época, nas rebeliões de rua as forças repressivas eram o alvo mais freqüente do povo rebelado: a fúria popular voltava-se contra o chefe de Polícia, o comandante da Brigada Policial, os policiais e os guardas civis, os quartéis, os postos policiais e o prédio do Ministério da Justiça (54).

\section{A desqualificação dos pobres}

O eficientíssimo artifício ideológico domesticador que se articulou nesse período, em íntima relação com o discurso científico, foi a disseminação pelo corpo social de uma imagem negativa dos pobre, vírus poderoso que naturalizava a condição social de uma classe aos olhos de todos e justificava a exploração econômica, a rudeza do aparato repressivo e o exercício oligárquico do poder. Foi a partir de então que as teorias raciais começaram a desempenhar aqui o papel que vinham desempenhando na Europa desde o século anterior, e que Hobsbawm resume como recurso ideológico de justificação do domínio de brancos sobre não-brancos, de ricos sobre pobres, de "civilizados" sobre "primitivos". A presença no Brasil de críticas à desigualdade e à opressão capitalistas gerou, nesse período, a necessidade de justificá-las, pois “o liberalismo não tinha nenhuma defesa lógica diante dos clamores de igualdade e democracia; portanto, a barreira ilógica do 
racismo foi levantada: a própria ciência, o trunfo do liberalismo, podia provar que os homens não são iguais", o que permite ao autor de $A$ era do capital concluir que "o darwinismo social e a antropologia racista pertencem não à ciência do século XIX, mas à sua política” (55).

A sutileza disciplinadora ficou por conta de um eficiente deslizamento semântico, cujo resultado foi uma profunda e metódica desqualificação dos pobres, de presença duradoura na cultura brasileira: apoiado na ciência, o discurso oficial substituiu os termos emprestados da demonologia, que anteriormente definiram a natureza do povo insubordinado (56), e pobreza passou a significar sujeira, que significava doença, que significava degradação, que significava imoralidade, que significava subversão. A doença não era só um mal do físico, mas deteriorização da alma, da raça, que se traduzia nos mais variados vícios: alcoolismo, promiscuidade sexual, negligência dos deveres paternos, vadiagem, crime, baderna anarquista. Doenças físicas, hábitos tidos como viciosos e sentimentos de revolta eram todos postos sob o mesmo rótulo de patologia (57).

Nos documentos oficiais, na imprensa, nos relatórios e pareceres dos especialistas vai-se constituindo um vasto rol de termos infamantes para designar os pobres: degenerados, anormais, selvagens, ignorantes, incivilizados, feios, desordeiros, rudes, grevistas, incapazes, preguiçosos, boêmios, anarquistas, brutos, irresponsáveis, desregrados, perniciosos, bêbados, farristas, decaídos, nocivos, arruaceiros, desocupados, marginais, deletérios, animalescos, simiescos, medíocres, sujos, libertinos, trapaceiros, parasitas, vadios, viciados, ladrões, criminosos. Rótulos pejorativos atingiam também as famílias das classes populares; baseados em Le crime dans la famille, da autoria de um juiz francês encarregado de processos de menores e estudioso das relações entre dissolução e desorganização familiar e delinqüência infantil e juvenil, os nossos especialistas falavam em "pais imprestáveis" e classificavam-nos em três grupos: negligentes, incapazes e indignos. A ciência afirmava que os vícios, tal como as doenças do corpo, encontravam terreno mais propício em certas nacionalidades e em determinadas raças, tidas como biologicamente inferiores.

Em 1871, Silvio Romero, adepto da crença na inferioridade das raças formadoras da nacionalidade brasileira e de seu povo mestiço, afirmava a condição "bestamente atrasada" e "bestamente infecunda" dos ameríndios e a natureza "estupidamente indolente" e "estupidamente talhada para escravo" dos "selvagens africanos", que explicariam "o nulo desenvolvimento de nossas letras e a nenhuma originalidade do nosso gênio" (58). Mas à medida que se aproximou o fim do Império o negro e o mulato, mais que o índio, passaram a ser objeto da atenção da ciência e a arcar com o peso da 
responsabilidade pelo "corrompimento social” em que o país se encontraria. A condenação do cruzamento racial, que levou à afirmação generalizada de que a realidade brasileira era palco da "anarquia das raças" e do "perigo da delinqüência” e fez da mestiçagem o maior mal do país, encontrou acolhida nas faculdades de medicina e teve no médico baiano Raimundo Nina Rodrigues seu porta-voz mais enfático. Na confluência da preocupação com o "caos social" e da tese da degeneração trazida pela mistura racial, as idéias de Lombroso e Ferri levaram o grupo de Nina Rodrigues a dar início à Medicina Legal no Brasil, tema freqüente na Gazeta Médica da Bahia durante algumas décadas.

A Escola Italiana de Criminologia tinha como centro a tese segundo a qual os pobres eram especialmente predispostos ao crime. Características físicas mensuráveis - traços fisionômicos, proporções e formas de várias partes do corpo - eram tomadas como indicadores inequívocos de tendências psíquicas e morais e tornavam-se os novos espelhos da alma. A antropologia criminológica científica pretendia ter chegado ao protótipo do criminoso e usava-o para fins de previsão da conduta. Negros, mestiços e imigrantes pobres estavam no foco do olhar preconceituoso de cientistas que queriam ver implantadas aqui as técnicas que cartografavam corpos em busca de "sinais lombrosianos" de anormalidade do caráter, não sem muita pose e certezas delirantes. Nos estudos de Enrico Ferri sobre os "estigmas e anomalias atávicas" o biótipo do "criminoso nato" correspondia ao biótipo do negro (59).

Em 1897, o delegado de polícia Cândido Motta apresentava uma dissertação na Faculdade de Direito de São Paulo na qual apontava semelhanças entre a constituição física de líderes anarquistas europeus e a dos criminosos (60). Em 1925, Dr. Esposel, professor de neuro-psiquiatria da Faculdade de Medicina e de higiene na Escola Normal do Rio de Janeiro, pregava a profilaxia “das psiconeuroses ou mesmo do nervosismo sem rótulo, de distúrbios elementares do sistema nervoso (...) que podem gerar paixões, crimes, idéias extremistas, reivindicatórias ou revolucionárias" (61). Durante todo o período primeiro-republicano os nossos intelectuais não cansaram de afirmar que "uma nação mestiça é uma nação invadida por criminosos" e de expressar preocupação com o "estado de delinqüência social do povo brasileiro."

Desse ponto de vista, o povo adoecia e infringia as leis não porque submetido à mais completa miséria, e o ativista político rebelava-se não porque a injustiça fosse real e revoltante, mas porque povo e rebeldes eram feitos de raças inferiores predispostas à doença física e mental, ao crime e à insubordinação. 
Levada às últimas conseqüências, a tese do determinismo racial resultou não na aplicação generalizada de procedimentos antropométricos, mas na previsão de um futuro sombrio para o país: "de fato, tendo como base os modelos poligenistas do darwinismo social, pouco se poderia esperar de uma nação composta por 'raças pouco desenvolvidas como a negra e a indígena', isso sem falar dos mestiços, maioria absoluta em nossa população" (62). A saída que se configura nos anos 20 é a tese da reversibilidade da degeneração racial. Depois da fase inicial de apropriação mimética das teorias raciais que se deu no Império e nos primeiros anos republicanos, o impasse criado pela concepção do povo brasileiro como biologicamente degenerado levou os intelectuais à "originalidade do pensamento racial brasileiro"; uma costura engenhosa de evolucionismo e darwinismo social permitiu, segundo Schwarcz, enxergar saídas para o país sem que se precisasse negar a inferioridade dos pobres: "do darwinismo social adotou-se o suposto da diferença entre as raças e sua natural hierarquia, sem que se problematizassem as implicações negativas da miscigenação. Das máximas do evolucionismo social sublinhou-se a noção de que as raças humanas não permaneciam estacionadas, mas em constante evolução e 'aperfeiçoamento', obliterando-se a idéia de que a humanidade é una" (63).

Acima das falas dos que começavam a defender a necessidade de promover junto ao povo melhores condições de vida, soavam palavras de ordem pautadas na tese da inferioridade de um povo mestiço e negro e que só diferiam quanto às estratégias recomendadas para revertê-la. As medidas higiênicas remediativas e profiláticas prescritas incluíam desde o incentivo à prática da educação física e os exames pré-nupciais, até soluções protofascistas, como estimular casamentos de não-brancos regeneráveis com brancos hígidos; deixar que os irremediavelmente degenerados se reproduzissem entre si, na esperança de apressar sua extinção; impedir casamentos, vetar a atividade sexual, esterilizar e confinar indivíduos tidos como "degenerados" ou "anormais irrecuperáveis". Os que defendiam o incentivo do branqueamento por meio de casamentos inter-raciais faziam-no não porque acreditassem na igualdade entre os homens, mas porque o viam como "condição de vitória do branco no país" (64), o que significava nada mais nada menos do que a exclusão dos negros do projeto de Nação.

A obra de Oliveira Vianna é paradigmática desse trajeto das idéias políticas na Primeira República: tido como "o maior místico do arianismo que ainda surgiu entre nós" (65), fez a síntese de evolucionismo e darwinismo social e passou da crença na degradação do mestiço para a idéia de branqueamento, à procura de saída salvadora para o país. 
Entre os que pregavam as medidas mais drásticas de aprimoramento da raça estavam os médicos psiquiatras que fundaram no Rio, em 1923, a Liga Brasileira de Higiene Mental, agremiação que participava com entusiasmo da ideologia "xenófoba, racista, antiliberal e moralista" predominante em instituições científicas e culturais no primeiro período republicano (66). Na revista da Liga eram muitos os artigos sobre imigração que se referiam com alarme aos perigos do ingresso no país de "deficientes morais".

Em 1925, Juliano Moreira, então diretor geral da Assistência aos Alienados, presidente da Sociedade Brasileira de Neurologia, Psiquiatria e Medicina Legal e presidente de honra da Liga Brasileira de Higiene Mental, manifestava-se a favor do "repatriamento de muitos psicopatas estrangeiros”, não só porque os via como peso econômico, mas também porque "elementos maus" vindos de terras estranhas ameaçavam a saúde mental da nacionalidade brasileira, e pregava o veto ao ingresso de qualquer portador de perturbação mental congênita ou adquirida: "nenhum idiota, nenhum imbecil evidente, nenhum demente de qualquer espécie, nenhum epilético, nenhum maníaco-depressivo, nenhum parafrênico, nenhum paranóico, nenhum doente de qualquer outra psicose definida poderá saltar em nenhum porto nacional e se entrar pelas fronteiras terrestres deverá ser repatriado, mesmo que seja à custa da nação" e indicava os manicômios como lugares valiosos de profilaxia pela “seqüestração" (67).

No mesmo ano, o Dr. Esposel sugeria mudanças de rumo no programa da Liga, entre as quais "pugnar com mais veemência pela incapacidade matrimonial dos degenerados, dos oligofrênicos depois de certo grau, dos doentes mentais, mesmo daqueles que percorrem período remissivo, mas nos quais uma nova crise da doença é previsível, e sobretudo dos que manifestam doenças cuja herança é conhecida e conduz à formação de famílias desequilibradas” (68).

Durante os anos 20, Julio Porto-Carrero, médico do Corpo de Saúde da Marinha, professor da Faculdade de Direito e vice-presidente da Liga Brasileira de Higiene Mental, defendia o exame pré-nupcial como fator eugênico nos mesmos termos do apuramento de raças levado a efeito por criadores de porcos, bois e cavalos de corrida.

Renato Kehl, um dos médicos mais radicais e combativos da LBHM na defesa da Eugenia, recomendava a esterilização de degenerados e lamentava a oposição dos que defendiam os "melindráveis direitos individuais" à idéia de esterilização e tratava de justificar um "vasto programa de propósitos defensivos e evolutivos da espécie" que visava à realização do "magno problema 
da criação da elite eugênica”, valendo-se de argumentos presentes na agricultura, na pecuária e no exemplo de países pioneiros nessa prática, nos quais haviam sido esterilizados centenas de "criminosos, loucos, idiotas, epiléticos, cancerosos, nefríticos, tuberculosos, prostitutas, vagabundos, alcoólatras, ninfomaníacas e homossexuais”. O objetivo era impedir a procriação dos portadores de mau caráter (os "cacopathas") e dos "desgraçados (...) que ameaçam a comunidade e enchem cada vez mais asilos e prisões” (69).

Nesse vasto programa eugênico a infância compareceu como lugar privilegiado de prevenção do crime e da loucura: " é na idade infantil que a higiene mental encontra o seu máximo de utilidade prática, justificando a intensificação de sua ação salvadora nessa fase da existência, quando as condições de receptividade para os bons princípios a que é solicitada melhor se revelam", dizia em 1925 o Dr. Heitor Carrilho, diretor do Manicômio Judiciário do Rio de Janeiro, projeto compartilhado pelos educadores escolanovistas que então planejavam reformas inviáveis do ensino fundamental.

Em 1898, Francisco Franco da Rocha adotou as idéias de Pinel e fundou o Hospital dos Alienados do Juquery. Os objetivos proclamados eram permitir a pesquisa e o progresso do conhecimento sobre a doença mental; garantir a supervisão dos trabalhos pelos poucos médicos especializados existentes na época; classificar os doentes e separá-los por pavilhões, em função da natureza da patologia, e instituir o trabalho agrícola terapêutico, tudo isso em nome do bem-estar dos internos, de sua recuperação ou, nos casos irrecuperáveis, de tratamento mais humano. No entanto, as condições de vida oferecidas às pessoas encaminhadas ao grande asilo situado na periferia da cidade de São Paulo sempre estiveram em desacordo com o discurso humanitário que o fundou.

Sob a retórica da regeneração, a crença na degeneração de um povo feito de raças inferiores dava forma ao cotidiano institucional, em consonância com o arranjo brasileiro de evolucionismo e darwinismo social: o otimismo terapêutico afinava os nossos vaidosos especialistas com os cientistas europeus e com o projeto de salvação do país; a crença na degeneração do povo brasileiro justificava o uso do hospício como instituição paramilitar que condenava à prisão perpétua e à morte imigrantes e não-brancos pobres (a maioria da população de internos) tidos como ameaça ao projeto saneador da raça brasileira. Encobertas pelo discurso filantrópico do fundador, celasfortes e rotundas aprisionavam os menos dóceis. As práticas terapêuticas incluíam técnicas de espancamento cientificamente justificadas: inocular malária nos "paralisados" era uma delas; aplicar uma paulada violenta no estômago era outra, tida como "descoberta científica” de Franco da Rocha, festejado por seus pares como criador da "terapia de choque" (70). 
A historiadora Maria Clementina Pereira Cunha abriu os arquivos do Juquery e trouxe à luz registros de horrores vividos no local. Tanto os laudos dos especialistas quanto as denúncias e pedidos de socorro escritos pelos internos - gritos que ficaram amordaçados durante décadas nos arquivos mortos da instituição - falam de terror. Nos prontuários, as fotos mostram rostos jovens; muitas mulheres; homens nus, quase todos negros; crianças e velhos; olhares inteligentes que depois se apagam; corpos dobrados sob o peso da humilhação e da impotência. Os negros - e, mais ainda, as mulheres negras - integram o contingente de "não-regeneráveis"; provam-no os veredictos presentes nos prontuários de duas mulheres negras: num deles, o laudo médico afirma que "os estigmas de degeneração física que apresenta são os comuns de sua raça: os lábios grossos, nariz esborrachado, seios enormes, pés chatos"; noutro, sentencia: "estigmas físicos de degeneração muito acentuados: é um perfeito tipo de símio" (71), diagnósticos consonantes com a visão de Franco da Rocha, que em 1911 afirmava num artigo sobre loucura na raça negra publicado na França: “até o presente, o estado rudimentar da mentalidade nesta raça nada ganhou; ele ainda se mantém muito baixo, comparado ao das raças brancas que existem aqui” (72).

Mas o Juquery não era instituição médica que disciplinava, pois a quase totalidade dos internos não era devolvida à sociedade domesticada, regenerada ou qualificada para o trabalho. Havia exploração dos que trabalhavam nas colônias agrícolas criadas por Franco da Rocha a título de laborterapia; o número de desinternados e assimilados ao mercado de trabalho foi, ao que tudo indica, muito pequeno. Ao serem internados, eram extirpados do corpo social, quase sempre sem volta, pois a mortalidade era altíssima em função das epidemias freqüentes, da falta de higiene, do desamparo, das internações longas, não raro vitalícias. $\mathrm{O}$ discurso psiquiátrico foi instrumento importante de legitimação da imensa desigualdade social e de condução autoritária da vida política, mas a presença dos médicos no espaço urbano foi menos intensa e direta do que pode parecer à primeira vista, não só porque não conseguiam atrair interesse dos poderes públicos para muitos de seus projetos - prova-o a luta inglória do pediatra carioca Moncorvo Filho pela obtenção de recursos estatais para a criação de instituições de puericultura e de atendimento médico a crianças pobres (73) -, mas também porque a grande executora de suas idéias era a polícia, que agia como bem entendia. O Juquery foi braço da polícia, foi cadeia, não porque a polícia não desse conta de seu papel e precisasse de auxílio da ciência para "conferir legitimidade à exclusão de indivíduos ou setores sociais não totalmente enquadráveis nos dispositivos penais" (74). 
Naquela época, como hoje, não era preciso que os pobres coubessem no Código Penal para que fossem alvo da sanha policial. Num país de tradição escravista, de relações de classe marcadas pela violência e pelo arbítrio, propostas científicas transformavam-se em agressão física executada por leigos brutais. Portadora de desrespeito secular pelo povo, a polícia prendia a três por dois e produzia dados que comprovavam as teses da ciência (75). O que alquebrava a resistência dos que sobreviviam ao extermínio não era, portanto, o disciplinamento invisível orientado pelo saber médico, mas a repressão policial, a reclusão e a auto-imagem arruinada pela assimilação de uma representação social negativa dos subalternos que a ciência passou a caucionar.

Lima Barreto foi levado pela polícia ao Hospital Nacional dos Alienados em 25 de dezembro de 1919. Dez dias depois registrou em seu diário: "não me incomodo muito com o hospício, mas o que me aborrece é essa intromissão da polícia em minha vida" (76). No ambiente que ele chama de "domínio do Senhor Juliano Moreira" os internos "são de proveniências as mais diversas; originam-se, em geral, das camadas mais pobres da nossa gente pobre. São pobres imigrantes italianos, portugueses, espanhóis e outros mais exóticos; são negros roceiros, (...) são copeiros, são cocheiros, cozinheiros, operários, trabalhadores braçais e proletários mais finos: tipógrafos, marceneiros etc." O tratamento dispensado aos "loucos desprotegidos e sem dinheiro" é diferente da condição hospitalar dos que têm "pistolão". O europeísmo de nossos intelectuais um fato: “... é bem sabido que os especialistas, sobretudo de países satélites, como o nosso, são meros repetidores de asserções das notabilidades européias, dispensando-se do dever mental de examinar a certeza das suas teorias, princípios etc., mesmo quando versam sobre fatos ou fenômenos que os cercam aqui, dia e noite, fazendo falta, por completo, aos seus colegas da estranja."

Assim como o século XIX europeu foi lugar dos modos capitalista e anticapitalista de pensar, o entendimento dos problemas sociais no começo do século XX brasileiro não se fez tão-somente de adesão sem reservas ao determinismo biológico ou à sociologia funcionalista, mas também de contestação dessas idéias e de análises do país a partir de outros compromissos políticos presentes em outras referências teóricas. Além de artigos de crítica social de inspiração bolchevista, Lima Barreto resumiu com sarcasmo e desengano os 20 primeiros anos de provincianismo, prepotência e barbárie da República em Triste fim de Policarpo Quaresma. O subsecretário do Arsenal da Guerra, conhecido como major Quaresma, é homem simples, pacífico, de boa-fé, imbuído de patriotismo sincero e tardio. Traz na alma um sentimento nativista que não cabe no Brasil endividado e 
colonizado de Floriano Peixoto. Nada escapa ao narrador: a "inércia da sociedade", que mais se assemelha ao marasmo imperial; as leis usadas pelos caciques locais para torturar e desmoralizar os inimigos políticos e o povo; a mediocridade geral da burguesia que corre atrás de um emprego público, de uma recomendação influente, de prestígio social, qualquer que seja o meio: a bajulação; a covardia; os falsos sentimentos afivelados no rosto; as convicções políticas ao sabor dos ventos momentâneos; os modos de falsa nobreza; a "ferocidade interesseira"; o culto ao doutorado, materializado no anel de doutor, parte do corpo sem a qual não se pode ir à rua sem correr o risco da perda de identidade.

Os médicos, sempre dedicados à ascensão social e monetária, afetam erudição e escrevem "artigos, estiradas compilações, em que não havia nada de próprio, mas ricos de citações em francês, inglês e alemão." Mas o principal objeto de escárnio são os militares, os "patriotas republicanos", seja Floriano Peixoto e sua entourage de cadetes da Escola Militar, sejam os oficiais reformados, herança do Império e da guerra do Paraguai. Os velhos generais e almirantes desativados são funcionários lentos e rotineiros, destituídos de inteligência, têm horror dos livros e passam a vida no "anonimato papeleiro" de ofícios, textos de regulamentos e boa caligrafia. Nas reuniões sociais contam "batalhas em que não estiveram e pugnas valorosas que não pelejaram". Os jovens oficiais de baixa patente, "falange sagrada", "chusma de oficiais subalternos e cadetes" com pendor ao despotismo, faziam de Floriano artigo de fé, tinham pela forma republicana adoração fetíchica e eram "adeptos desse nefasto e hipócrita positivismo, um pedantismo tirânico, limitado e estreito, que justificava todas as violências, todos os assassínios, todas as ferocidades em nome da manutenção à ordem”.

O governo do Marechal de Ferro "não era o despotismo, nem a democracia, nem a aristocracia, era o de uma tirania doméstica", era invasão do espaço público pelas regras da vida privada patriarcal. Num "país perdido", prestes a tornar-se "colônia inglesa", os militares republicanos fazem do povo bucha de canhão em batalhas ridículas movidas a vaidade $\mathrm{e}$ interesses pessoais. A Revolta da Armada é descrita com sarcasmo e demole o mito do heroísmo dos profissionais de farda: o quartel do batalhão patriótico Cruzeiro do Sul é um velho cortiço interditado pelos higienistas; o instrutor do batalhão é coxo e, no calor da batalha, "os oficiais pouco aparecem" e o "homem do canhão" atrasa-se, como pacato funcionário público. Num país que só se assemelhava à Europa no "rigor londrino da miséria", um nacionalista ingênuo e sincero terminou aniquilado pela máquina repressiva do ditador republicano, não sem antes reconhecer, com 
melancolia, que a idéia de Pátria não passava de manobra que facilitava a ação dos donos do poder (77).

Em 1902, Euclides da Cunha, embora sob influência das lições antropológicas de Nina Rodrigues, termina Os Sertões deixando entrever disposição para examinar as mazelas do país de ângulos mais críticos. Quando descreve os últimos dias da batalha, denuncia a matança de gente miserável cujo único crime foi ter a esperança de redenção renovada pelas promessas de bem-aventurança trazidas por um fanático. Depois de relatar, não sem horror, a exumação de Conselheiro para que "a ciência dissesse a última palavra" - pois que "ali estavam no relevo de circunvoluções expressivas as linhas essenciais do crime e da loucura..." - conclui com duas linhas de muita ironia: "é que ainda não existe um Maudsley para as loucuras e os crimes das nacionalidades...” (78). E na edição de 1 de maio de 1904 de $O$ Estado de S. Paulo expôs com simpatia as idéias de Marx sobre a exploração capitalista, a socialização dos meios de produção e a revolução proletária (79).

Organizações operárias, partidos políticos e intelectuais faziam críticas à ordem social e contrapunham-se aos rótulos que estigmatizavam os oprimidos. Em artigo publicado em 1917, no primeiro número de um hebdomadário anarquista, o advogado Benjamin Motta rebatia nos seguintes termos a matéria publicada no Correio Paulistano, na qual se afirmava que só é pobre quem é vadio: “Oh! aberração da vista e da inteligência! Só é pobre quem é vadio? O número de pobres no Estado de S.Paulo sendo de nove décimos da população, segue-se que nove décimos dos habitantes do Estado são vadios. (...) Só é pobre quem é vadio! Mas então o operário que labuta doze ou quatorze horas por dia, para ganhar $3 \$ 000$ ou $4 \$ 000$ e que no fim do mês não tem o suficiente para o aluguel do tugúrio que habita e para pagar o vendeiro e o padeiro, é um vadio? (...) 'Em São Paulo, afirma o Correio, só não ganha dinheiro quem não trabalha.' É justamente o contrário que se dá. Em São Paulo, como em toda a superfície da terra, só ganha dinheiro quem não trabalha. (...) A fortuna acumulada, disse-o Carl Marx, e ninguém poderá demonstrar o contrário, é produto exclusivo do trabalho não pago. Logo, quem trabalha não ganha dinheiro porque o lucro é todo do patrão, e o pobre não é um vadio, é apenas a vítima lastimável de uma péssima e detestável organização social" (80).

Problematizar a transposição integral das idéias de Foucault sobre o disciplinamento sutil para o Brasil do começo deste século não significa negar que se iniciava naquele período a fragmentação e a especialização das instituições de vigilância e punição, nem dizer que não se desenhavam então técnicas e programas mais refinados de domesticação das condutas. Nos 
laboratórios de Psicologia que começavam a pesquisar e disseminar os tests; no discurso dos educadores que encareciam o papel disciplinador da escola; nas prescrições dos juristas de expansão e modernização de reformatórios; nas obras de médicos dedicados à pediatria e à puericultura; nas vozes que recomendavam a criação de clínicas de higiene mental e de orientação infantil anexas às escolas públicas e outros procedimentos de prevenção baseados nos princípios de uma Psicologia nascente que enfatizava a educação precoce de hábitos e a classificação dos indivíduos segundo as "aptidões naturais", em todos esses propósitos estavam as sementes de práticas mais refinadas de controle social informadas pela ciência, que se fariam mais presentes a partir do segundo período republicano.

Notas

1 Cf. Viotti da Costa, E. Sobre as origens da República. In: Da Monarquia à República. momentos decisivos, $6^{\text {a }}$ ed. São Paulo, Brasiliense, 1994, p. 266-320.

2 Cruz Costa, J. Pequena história da República. São Paulo, Brasiliense/CNPq, 1988, p. 41 (1 a ed.: 1968).

3 Id., p. 42

4 Fausto, B. História do Brasil. São Paulo, Edusp/FDE, 1995, p. 305-318, passim.

5 Pinheiro, P.S. Classes médias urbanas: formação, natureza, intervenção na vida política. In: B. Fausto (org.). História geral da civilização brasileira, v. 9. São Paulo, Difel, 1989, p. 15.

6 Viotti da Costa, E., op. cit., p. 334-335.

7 Carvalho, J.M. de. Os bestializados. O Rio de Janeiro e a República que não foi. São Paulo, Companhia das Letras, 1997, p. 32.

8 Id., p. 85-89, passim.

9 Fausto, B., op. cit., p. 281.

10 Cf. Pinheiro, P.S. O proletariado industrial na Primeira República. In: Boris Fausto (org.). História geral da civilização brasileira, v. 9, p. 146 e 149.

11 Antonio Candido, Prefácio. In: Cruz Costa, J. Pequena história da República, p. III, $3^{a}$ ed., 1989.

12 Rago, M. Do cabaré ao lar. A utopia da cidade disciplinar. Rio de Janeiro, Paz e Terra, 1985, p. 27-31. 
13 Viotti da Costa, E., op. cit., p. 120-136, passim.

14 Id., p. 247.

15 Cruz Costa, J., op. cit., p. 91.

16 Foucault, M. Vigiar e punir. São Paulo, Vozes, 1987.

17 Fausto, B. Trabalho urbano e conflito social. São Paulo, Difel, 1986, p. 237.

18 Id. Controle social e criminalidade em São Paulo: um apanhado geral (18901924). In: P.S. Pinheiro (org.). Crime, violência e poder. São Paulo, Brasiliense, 1983, p. 193-223; Fausto, B., Crime e cotidiano. A criminalidade em São Paulo (1890-1924). São Paulo, Brasiliense, 1984.

19 Linebaugh, P. Crime e industrialização: a Grã-Bretanha no século XVIII. In: P.S. Pinheiro (org.). Crime, violência e poder, p. 106 e 123.

20 Fausto, B. Trabalho urbano e conflito social, p. 243.

21 Sobre a diversidade de setores e ocupações que absorviam as classes trabalhadoras na São Paulo da Primeira República, veja Pinto, M.I.B. Cotidiano e sobrevivência. A vida do trabalhador pobre na cidade de São Paulo (18901914). São Paulo, Edusp/Fapesp, 1994. Veja também Bosi, E. Memória e sociedade. Lembranças de velhos. São Paulo, Cia. das Letras, 1994.

22 Pinto, M.I.B., op. cit., p. 194-195.

23 Id., p. 186-187.

24 Id., p. 198.

25 Id., p. 187.

26 Fausto, B. Controle social e criminalidade em São Paulo ..., p. 207.

27 Silva, L. Comentário ao texto de Boris Fausto. In: P. Sérgio Pinheiro (org.). Crime, violência e poder, p. 212.

28 Fausto, B. Controle social e criminalidade em São Paulo, cit., p. 199-200.

29 Id., p. 202.

30 Cf. relatório do chefe da polícia da capital paulista, apud Boris Fausto, id., p. 203-204.

31 Fausto, B. Controle social e criminalidade, cit., p. 205 (grifos meus).

32 Moreira, S. São Paulo na Primeira República. São Paulo, Brasiliense, 1988, p. 8.

33 Fernandes, H.R. A força pública do estado de São Paulo. In: Boris Fausto (org.). História geral da civilização brasileira, v. 9, p.244. 
34 Fausto, B. Trabalho urbano e conflito social, p. 240.

35 Mello e Souza, L. de. Tensões sociais em Minas na segunda metade do século XVIII. In: Adauto Novaes (org.). Tempo e história. São Paulo, Cia das Letras/ Secretaria Municipal de Cultura, 1993, p. 360.

36 Fausto, B. Trabalho urbano e conflito social, p. 235.

37 Benchimol, J.L. Pereira Passos: um Haussmann tropical. Rio de Janeiro, Secretaria Municipal de Cultura, Turismo e Esporte. Departamento Geral de Documentação e Informação Cultural, 1992, caps. 11 e 12, p. 192-234, passim.

38 Cf. Rago, M., op. cit., p. 163-175.

39 Nesta mesma linha interpretativa, o historiador J. Needell ressalta a diferença de propósitos das reformas urbanas da Paris da segunda metade do século passado e do Rio da segunda década republicana: o barão de Haussmann queria uma cidade bela, eficiente e saudável, mas também executar um plano urbanístico de natureza contra-revolucionária, atacando "os bastiões da revolta da classe trabalhadora"; o engenheiro e prefeito carioca Pereira Passos tinha um plano de urbanização de caráter antitradicionalista, fincado em padrões de eficiência, saúde e beleza à européia, mas queria também executar um ataque "aos bastiões de um meio essencialmente brasileiro e sua cultura afro-brasileira, incompatível com a transformação do Rio em vitrine da Civilização". In: Belle époque tropical. São Paulo, Cia. das Letras, 1993, p. 65-73, passim.

40 Carvalho, J.M de, op. cit., p.162.

41 Mello e Souza, L., op. cit., p. 352-358.

42 Viotti da Costa, E., op. cit., p. 127-128.

43 Azevedo, C.M.M. Onda negra, medo branco. O negro no imaginário das elites - século XIX. Rio de Janeiro, Paz e Terra, 1987.

44 Carrilho, H. Considerações sobre prophylaxia mental e delinqüência. Arch. Bras. de Hygiene Mental, ano I, n. 1, p. 131, 1925.

45 Apud Schwarcz, L.M. O espetáculo das raças. São Paulo, Cia. das Letras, 1994, p. 178.

46 Engels, F. La question du logement. Paris, Éditions Sociales, 1969, p. 27.

47 Id., p. 88.

48 Carvalho, J.M. de, op. cit., p. 41.

49 Sobre esse processo, veja Boltanski, L. Primme éducation et morale de classe. Paris, École des Hautes Études en Sciences Sociales, 1984. 
50 Perrot, M. Funções da família. In: M. Perrot (org.). História da vida privada, v. 4. São Paulo, Cia. das Letras, 1992, p. 111-112.

51 Hall, C. Sweet home. In: M. Perrot (org.), op. cit., p.75.

52 Chauí, M. de S. Cultura e democracia. O discurso competente e outras falas. São Paulo, Moderna, 1980, p. 47.

53 Antonio Candido. Dialética da malandragem. In: O discurso e a cidade. São Paulo, Duas Cidades, 1993, p. 50-51, passim.

54 Carvalho, J.M, op. cit., p. 133.

55 Hobsbawm, E. A era do capital. Rio de Janeiro, Paz e Terra, 1979, p. 277.

56 Mello e Souza, L. de, op. cit., p.351.

57 A idéia de "deslizamento semântico" surgiu da leitura de Rago, M., op. cit., em especial p. 190.

58 Romero, S. O caráter nacional e as origens do povo brasileiro, 1871. In: S. Romero. Etnologia selvagem, 1875. Cf. Mendonça, C.S. Silvio Romero. sua formação intelectual (1851-1880). São Paulo, Cia. Ed. Nacional, Col. Brasiliana, v. 114,1938 , p. $74-75$.

59 Rocha, L.C. A prisão dos pobres. São Paulo, 1994. Tese (doutorado), Instituto de Psicologia da USP, p. 116.

60 Rago, M., op. cit., p. 91.

61 Esposel, F. Idéas geraes de hygiene mental. Arch. Bras. de Hygiene Mental, ano I, n. 1, p. 105, 1925 (grifos meus).

62 Schwarcz, L.M., op. cit., p. 213.

63 Id., p. 18.

$64 I d .$, p. 154.

65 Freyre, G., Casa-grande e senzala, 28 ${ }^{\text {a }}$ ed. São Paulo, Record, 1992, p. 305.

66 Para uma análise da ideologia da Liga, veja Freire Costa, J. História da psiquiatria no Brasil, 4a ${ }^{\mathrm{a}}$. ed. Rio de Janeiro, Xenon, 1989.

67 Moreira, J. A seleção individual de immigrantes no programma da hygiene mental. Arch. Bras. de Hygiene Mental, ano I, n. 1, p. 113, 1925.

68 Esposel, F. Idéas geraes de hygiene mental. Arch. Bras. de Hygiene Mental, ano I, n. 1, p. 103, 1925 (o grifo é do autor).

69 Id., p. 71. No Brasil tais medidas não atingiram a extensão alcançada em outros 
países: enquanto na California foram esterilizados mais de seis mil pessoas tidas como débeis mentais e alienadas entre 1909 e 1929, há registro de 19 casos de esterilização realizados por ginecologistas da Faculdade de Medicina e Cirurgia de São Paulo, no mesmo período (cf. Romero, M., op. cit., p. 146 e 148), o que não abole a dimensão ética da questão.

70 Cunha, M.C.P. O espelho do mundo. Juquery, a história de um asilo, $2^{\text {a }}$. ed. Rio de Janeiro, Paz e Terra, 1988, p. 100.

71 Id., p.124.

72 Franco da Rocha, F. Contribution a l'étude de la folie dans la race noire. Annales Médico-Psychologiques, n. 69, p. 374, 1911.

73 Moncorvo Filho, A. Histório da proteção à infância no Brasil, 1500-1922, 2ª . ed., Rio de Janeiro, Empresa Gráfica Ed., 1926.

74 Cf. Cunha, M.C.P., op. cit., p. 80.

75 Romero, M., op. cit., p. 90.

76 Lima Barreto, A.H. O cemitério dos vivos. São Paulo, Brasiliense, 1956, p.3334 .

77 Id. Triste fim de Policarpo Quaresma. São Paulo, Brasiliense, 1959 (1 a . ed.: 1911).

78 Cunha, E. da. Os Sertões. São Paulo, Editora Três, 1973, p. 371-372. Maudsley foi um psiquiatra inglês autor de $O$ crime e a loucura, livro de grande prestígio na época.

79 Cunha, E. da. Um velho problema. In: Contrastes e confrontos. São Paulo, Cultrix/MEC, 1975, p. 144.

80 Motta, B. O pobre é um vadio? A Plebe, ano I, n. 1, p. 1-2, 9 jun. 1917.

RESUMO - A PARTIR DA RECONSTITUIÇÃO de especificidades econômicas, políticas e sociais da Primeira República brasileira, no presente ensaio problematiza-se a transposição direta e integral, para esse período da história do Brasil, da análise de Foucault das sociedades européias da virada do século XVIII, resultantes das revoluções industrial e política burguesas. Dando continuidade à tradição autoritária e clientelista das relações de classes no país, o primeiro período republicano pôs no arbítrio e na violência da polícia, mais do que na sutileza disciplinadora dos médicos, a tarefa de conter o "caos urbano". Se houve disciplinamento imposto pela ciência, ele foi sobretudo fruto da disseminação de uma representação social negativa, de cunho racista, dos integrantes das classes subalternas. 
ABSTRACT - STARTING FROM THE RECONSTITUTION of the economic, politic and social aspects of the First Republic in Brazil, this report questions the direct and total wholesome transposition to that Brazilian historical period of Foucault's view of the European societies from the turning of the eighteenth century. Carrying on a Brazilian tradition of an authoritarian and patronizing relationship between social classes, the first republican period relied on a despotic and violent police, rather than on the subtle disciplinarian medical ways, in its attempt to control "urban chaos". If science had any role on this practice, it resulted mainly from the dissemination of a negative racist social representation of the members of the underprivileged classes.

Maria Helena Souza Patto é docente do Instituto de Psicologia da Universidade de São Paulo.

Este artigo, concluído em março de 1997, é parte de uma pesquisa sobre a história do movimento brasileiro de higiene mental infantil realizada com o apoio parcial do CNPq. Rodrigo Ferraz de Camargo e Daniel Souza Patto colaboraram na pesquisa bibliográfica. 